\title{
Inspiration and Action: Life and Legacy of Jeannette Rankin
}

\author{
Libby V. Morris
}

Published online: 9 October 2009

(C) Springer Science + Business Media, LLC 2009

Last evening in the pouring rain, I walked through the University of Georgia campus to the Classic City Conference Center to attend the annual fund-raising dinner of the Jeannette Rankin Foundation (JRF). Following another long day occupied with administrative reports, urgent student and faculty requests, and attention to ongoing budget issues, I almost skipped the dinner and program. I am glad that I did not because I was once again inspired by the life of Jeanette Rankin and the legacy represented by the work of the Foundation bearing her name.

Jeannette Rankin (1880-1973) attended Montana State University, the New York School of Philanthropy (later the Columbia School of Social Work), and the University of Washington in Seattle. Her early involvement in the women's suffrage movement was a precursor to her becoming the first woman elected to U.S. Congress in 1916 as a republican from Montana. She advocated for peace, women's rights, and child welfare. An anti-war (peace vote) sealed her emerging political career; and after the war she moved to a farm in Georgia, close to the University of Georgia. From there she formed the Georgia Peace Society and worked with the National Council for the Prevention of War. She traveled throughout the United States., giving speeches on peace. In 1939, she returned to Montana; and once again she was elected to Congress. Rankin again voted "no" when Congress voted to declare war. At the end of her term, she returned to Montana and then traveled from there around the world working for peace (see http://womenshistory.about.com/od/congress/a/ jeanette_rankin.htm).

Currently, the Foundation awards approximately 80 scholarships annually to assist lowincome women age 35 and older to attend an institution of higher education in an undergraduate program. All see education as a way out of poverty and a career path through which they will be able to improve the lives of their families and communities. Hundreds of applications pour in every year, showing great financial need. Each applicant shares a hearttouching story of life challenges ranging from domestic violence to chronic illnesses to devastating job losses. The letters from references are often even more candid and almost pleading for these deserving women whom the letter writers know personally.

L. V. Morris $(\bowtie)$

Institute of Higher Education, University of Georgia, 102 Meigs Hall, Athens, GA 30602-6772, USA

e-mail: lvmorris@uga.edu 
The applications go through several rounds of review by local readers, many associated with the University of Georgia. Each spring I join tens of others as a reader with the responsibility for making recommendations about applicants, and this small act reminds me of the importance of making a difference now and into the future. This Foundation was founded in 1976 with $\$ 16,000$ provided by a bequest left by Jeannette Rankin. The first scholarship in 1978 totaled $\$ 500$. Today, JRF awards 80 scholarships amounting to $\$ 2000$ each.To date more than 1 million dollars have been awarded to women in every state over the last 31 years. Rankin's life was dedicated to the advancement of women; and it is fitting that the founders of the Foundation, five outstanding women in Athens, used the bequest to establish a significant legacy representative of her life.

Giving to the JR Foundation is a sound investment in the future. This modern day scholarship is even more meaningful because of the limited number of scholarships aimed at a large and underserved group of women who struggle to attend college. Donations come from membership dues, individual donations, business sponsorships, and circles of Rankin supporters across the nation.

Recipients are screened not only for their financial need, but for the perceived "grit factor", the ability to overcome odds and persist with just a little help. The intensive evaluation of applications shows excellent results: between 2006 and 2008, more than $95 \%$ of recipients had either already graduated or were continuing to make progress toward a degree. To learn more about the Foundation and to be inspired by a recipient story, go to http://www.rankinFoundation.org/.

Being innovative means not just having a dynamic idea, but being brave enough and dedicated enough and persistent enough to implement it. Jeannette Rankin was all of these things. She left a legacy for women. The readers of Innovative Higher Education are dedicated to changing and improving the lives of students and faculty in the academy. I thought you would be interested in knowing about one important effort to bring more nontraditional students into higher education. Last night's program was titled, "Creating Opportunities, Changing Lives.” Now that's a goal for today and tomorrow. 